\title{
On the selective adsorption of cations in the cell wall of the green alga Valonia utricularis
}

\author{
H. Kesseler \\ Biologische Anstalt Helgoland (Litoralstation); \\ D-2282 List/Sylt, Federal Republic of Germany
}

\begin{abstract}
The selective adsorption of the cations $\mathrm{Na}^{+}, \mathrm{K}^{+}, \mathrm{Mg}^{++}$and $\mathrm{Ca}^{++}$by the cell wall of the Mediterranean alga Valonia utricularis (Siphonocladales, Chlorophyceae) from sea water of $40 \% \mathrm{~S}$ was investigated by extraction of cell-wall preparations, eluted before in 1.1 mol methanol (adjusted to $\mathrm{pH} 8$ ) with $0.1 \mathrm{n}$ formic acid in a Soxhlet apparatus. $\mathrm{Na}^{+}$and $\mathrm{K}^{+}$were determined by flame photometry, $\mathrm{Mg}^{++}$and $\mathrm{Ca}^{++}$by complexometric titration with EDTA. From calculation of the dry weight:fresh weight ratios and the chloride determinations in the eluates, the Donnan freespace fraction of the total cell-wall volume was calculated to about $35 \%$, and the analytical results of the cation concentrations in the extracts expressed as $\mu \mathrm{Val} \mathrm{cm}{ }^{-3} \mathrm{DFS}$. This calculation is based on the assumption that the acidic groups of the noncellulosic matrix material, carrying negative charges by dissociation at the reaction of sea water (ph about 8 ) are responsible for the adsorption of cations by exhibition of a Donnan effect. The results obtained show clearly that besides the divalent cations $\mathrm{Mg}^{++}$and $\mathrm{Ca}^{++}$, which according to the physico-chemical laws of the Donnan distribution must be relatively accumulated to the second power of the monovalent ones, potassium is also enriched by selective adsorption, and the $\mathrm{K}^{+}: \mathrm{Na}^{+}$ratio increased significantly compared with that in sea water. This seems to indicate that the strength of attraction between the cations and the negative sites is dependent on the radii of the ions and the state of hydration and/or polarisation of the ions and binding sites.
\end{abstract}

\section{INTRODUCTION}

In higher plants the adsorption of ions by the cell walls of roots is the primary step and the triggering event in the chain of reactions involved in the uptake and accumulation of salts. Despite the simply physical nature of this reaction it is nevertheless a real accumulative process since the concentration of the ions at the adsorbing surfaces is commonly much higher than in the surrounding soil solution.

These conditions have long been recognized, and were closely investigated by many authors (Williams \& Coleman, 1950; Burström, 1951; Epstein, 1955; Kramer, 1956; Jacobsen et al., 1958; Lundegardh, 1958). In marine algae, however, the rôle of the cell wall in the mineral metabolism has scarcely been considered.

This may be due to the fact that in solutions of high ionic strength like sea water the Donnan effect, which is responsible for the adsorption of diffusible ions of the medium by fixed charges of opposite sign within the cell walls, is not so pronounced as in dilute media like the soil solution and freshwater. Therefore, its accumulative effect may be underestimated in sea water and its selectivity neglected or even simply overlooked.

It may, however, lead to the preferential adsorption not only of polyvalent cations, according to the physicochemical laws for the Donnan distribution of ions, but also to 
that of certain monovalent ones. This will depend in detail on the very complex interrelationships between the fixed charges (, sites") and the different ions according to the strength of attraction by Coulomb and non-Coulomb forces influencing the states of hydration and polarisation of sites and ions (Diamond \& Wright, 1969).

The disregard of these conditions may be the reason that very little information is available about the diffusion of ions across the cell walls, their ion-exchange properties and their spatial homogeneity (Hope \& Walker, 1975, p. 56f). The few data on this subject are scattered in the form of occasional and isolated observations. Moreover, they are concerned primarily with the conditions in freshwater algae, where, for the reasons mentioned above, the Donnan effect is more pronounced than in marine algae.

The only papers dealing with ion adsorption in dead tissue of a marine red alga are those of Eppley \& Blinks (1957) and Eppley (1957). They reported on the adsorption of $\mathrm{Ca}^{++}, \mathrm{Na}^{+}$, and $\mathrm{K}^{+}$in Porphyra perforata as well as on the exchange of adsorbed $\mathrm{Na}^{+}$for different mono-, di-, and trivalent cations from $0.1 \mathrm{n}$ solutions. While they could not detect any potassium in the Porphyra tissue killed by boiling or by immersion in cold $50 \%$ ethanol the ratios of the values reported for adsorbed $\mathrm{Ca}^{++}$and $\mathrm{Na}^{+}$correspond rather well with our results, as will be discussed later.

Besides these single observations on the ion contents in dead tissue of a marine alga, there are only three more papers dealing with the ion-exchange properties in cell-wall material of the freshwater algae Nitella axillaris (Diamond \& Solomon, 1959) and Chara australis (Dainty \& Hope, 1959; Dainty et al., 1960). The former authors studied the exchange kinetics of only ${ }^{42} \mathrm{~K}$ in the three main compartments (cell wall, cytoplasm and vacuole) of $N$. axillaris; from this they calculated the total potassium concentration in the single compartments. Dainty et al. (1960), on the other hand, investigated the exchange adsorption of labelled $\mathrm{Ca}^{*}$ and $\mathrm{Na}^{*}$ in the cell walls of $C$. australis. They also determined the concentration of the nondiffusible anions in the walls $\left(0.8 \mathrm{Vall}^{-1}\right)$ as well as the mean dissociation constant $(\mathrm{pK}=2.2)$ of the organic acids, from which the fixed cell wall anions are derived, and showed that the initial ion exchange took place in the Donnan phase of the cell walls.

This phase is defined as that fraction of the free space or outer space in plant cells and tissues (Kramer, 1957) in which the distribution of the diffusible cations and anions of the surrounding medium is influenced by the presence of the indiffusible anions of the wall material: while the mobile cations acting as counterions are attracted by the fixed negative charges, the diffusible anions or co-ions are repelled. Despite the unequal distribution of the mobile ions of opposite sign in the Donnan phase or Donnan free space (DFS), in the state of equilibrium their product must be equal to that in the environmental solution (Fig. 1).

In contrast to the DFS the water free space (WFS) is that part of the free space in which the concentration of the solutes is equal to that in the medium. For the determination of the free space of cells or tissues one has to take into consideration, therefore, that with different solutes, e. g. electrolytes and nonelectrolytes or even different kinds of both, different values are to be expected. Instead of the true free space for every solute only its apparent free space (AFS) will be obtained, defined as that part of free space to which the solute seems to move readily by diffusion (for further details see Briggs \& Robertson, 1957; Briggs et al., 1961; Levitt, 1957).

While information on the ion-exchange properties of algal cell walls is far from 
ample, no reliable data are available about the real concentrations and relations of the cations of the natural surrounding medium in cell walls of marine algae. This surely is due to the difficulties of obtaining pure cell-wall preparations from most species. For the investigations described below, the large celled coenocytic Mediterranean alga Valonia utricularis was chosen.

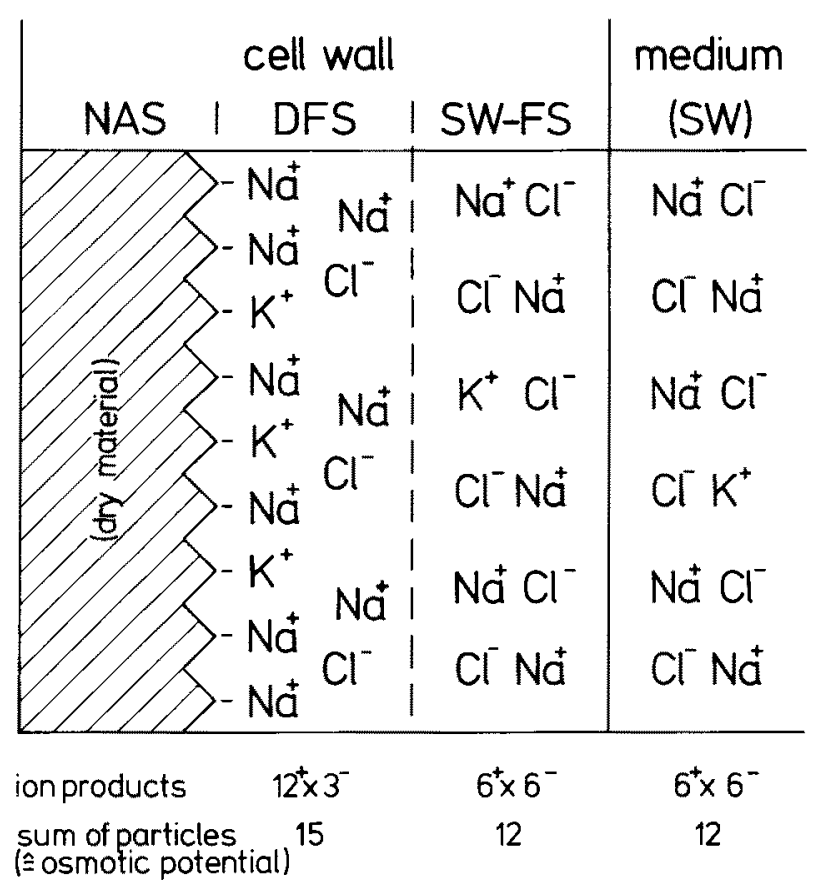

Fig. 1. Diagrammatic sketch of the ion distribution between the cell wall of a marine alga and the surrounding sea water. For reasons of simplification only the monovalent ions are symbolized. NAS $=$ non-accessible space $(\nRightarrow$ dry wall material); DFS $=$ Donnan free space containing the binding sites $(-)$ as well as their counterions of opposite charge $\left(\mathrm{Na}^{+}, \mathrm{K}^{+}\right)$and the co-ions $\left(\mathrm{Cl}^{-}\right)$of the same charge; $\mathrm{SW}-\mathrm{FS}=$ Sea water free space, i. e. that part of the cell wall (large pores and/or interfibrillar spaces) which is freely accessible by diffusion to all ions of the surrounding sea water in equal distribution while single ions or anelectrolytes may also enter the DFS in different concentrations according to their charges and their states of hydration and polarisation. ---- = potential barrier between DFS and SW-FS. In the state of electrochemical equilibrium the activity products of the diffusible ions must be equal in all compartments, while the sum of the diffusible particles, responsible for the magnitude of the osmotic potential, must be greater in the DFS than in the surrounding medium

\section{MATERIALS AND METHODS}

Vesicles of the Mediterranean chlorophycean Valonia utricularis, about $1.5 \mathrm{~cm}$ long and $0.5 \mathrm{~cm}$ in diameter, were used for the experiments. Some of these algae were brought to our laboratory from the Naples Zoological Station in 1964. The algae have since been cultivated in a temperature-constant room at $18^{\circ} \mathrm{C}$ in large $100-1$ tanks, made 
from polyvinyl chloride, in raw mass culture. They are kept free of diatoms and other epiphytes by the littoral molluscs Littorina littorea and Hydrobia ulvae as well as by different amphipods, isopods and other small animals, which usually graze on algae in the littoral zone. This cultivation method simulating natural conditions has proved to be successful and convenient even with other algae. Illumination is provided by fluorescent lamps in a day: night rhythm of $14: 10 \mathrm{~h}$ at an intensity of about $2000 \mathrm{~lx}$. Every week about one third of the sea water is replaced by freshly filtered water, enriched with $\mathrm{KNO}_{3}$ and $\mathrm{Na}_{2} \mathrm{HPO}_{4}$ if required. Evaporation by aeration causes salinity changes in the range of about $35-40 \%$. Under these conditions the algae flourish well: they are bright dark green and turgid.

For every experiment four sets of about 300 cells were used. The cell-wall preparations were obtained by squashing the vesicles and rubbing them between the fingers to remove the cytoplasm (Kornmann, 1934). After this treatment the cell walls were rinsed several times in sterilized sea water of $40 \% \mathrm{~S}$ and stored overnight in this medium. The next day the samples were centrifuged at 5000 r. p. m. (about $3000 \mathrm{~g}$ ) to remove the adhering sea water and then blotted by vigorous pressing between absorbent tissue. After weighing, the preparations (about $0.5 \mathrm{~g}$ each) were rinsed five times in $50 \mathrm{ml}$ of $1.15 \mathrm{~mol}$ aqueous methanol solution, isotonic to sea water of $40 \% \mathrm{~S}$, for several minutes to remove the sea water still adhering to the surface and to elute the diffusible ions from the AFS of the cell-wall material. Since the rinsing solution, adjusted to $\mathrm{pH} 8$ with Trisbuffer, contained practically not electrolytes, an exchange of cations adsorbed to the fixed negative charges (e. g. $\mathrm{COO}^{-}$groups) in the Donnan phase was prevented.

To liberate these cations from the material, the preparations were transferred to $150 \mathrm{ml}$ of $0.1 \mathrm{n}$ formic acid in a Soxhlet apparatus, and extracted for about $10 \mathrm{~h}$. The extracts were then concentrated to $50 \mathrm{ml}$ and used for the chemical analyses of $\mathrm{Ca}^{++}$and $\mathrm{Mg}^{++}$by titration with $10^{-3} \mathrm{~mol}$ EDTA as well as for the determination of $\mathrm{Na}^{+}$and $\mathrm{K}^{+}$ with a Leitz-Unicam SP 90 atomic absorption spectrophotometer.

Besides these determinations the first $50 \mathrm{ml}$ of the eluates were also analysed for $\mathrm{Cl}^{-}$, $\mathrm{Na}^{+}$, and $\mathrm{K}^{+}$. The $\mathrm{Cl}^{-}$values obtained by titration with $210^{-2} \mathrm{n} \mathrm{AgNO}_{3}$ were related to the $\mathrm{Cl}^{-}$content of the sea water; from these results the chloride apparent free space $(\mathrm{Cl}$ AFS) was calculated as per cent fresh weight ( $\% \mathrm{FW})$. The mean value from 12 determinations was $50 \%(50.13 \pm 2.6 \%)$.

However, as can be seen from Figure 1, the actual anion concentration in a Donnan phase containing negative binding sites must always be considerably lower than in the surrounding medium. Considering that the nonaccessible space of the material, calculated from the dry weight to fresh weight ratios, was about $30 \%$ and the Cl-AFS $50 \%$, it has to be concluded that the DFS must be greater than $20 \%$ and the WFS soaked with sea water, smaller than $50 \%$. Therefore, it cannot be far from reality to suppose that both spaces of Valonia cell walls are in the range of about $35 \%$. This is in good agreement with a communication of Preston (1974) who mentions that the matrix material in the cell walls of Valonia, which is supposed to be the seat of the negative binding sites, amounts to about one third of the cell-wall volume.

The analytical results listed in Table 1 are expressed in $\mu \mathrm{Val} \mathrm{cm} \mathrm{cm}^{-3} \mathrm{DFS}$. Although such a definition of "concentration" may be somewhat arbitrary, the author is conscious of the fact, that the application of this term to a gel phase of heterogeneous composition is always problematic. 


\section{RESULTS}

The first column of Table 1 (I SW $40 \%$ ) shows the concentrations of the single cations in sea water of $40 \%$ S calculated after Dietrich et al. (1975). In the second column

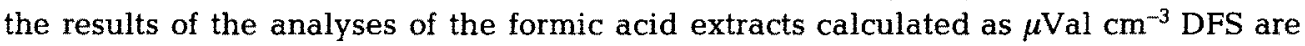
listed (I DFS); these figures are the mean values of six determinations each. The third and fourth columns give the ionic relations of the single cations compared with the total cation concentration in sea water (I SW/ $\Sigma$ I SW) and in the DFS (I DFS/ $\Sigma$ I DFS). The last column finally lists the ratios of the values of column four to those of column three (I DFS : $\Sigma$ I DFS/I SW : $\Sigma$ I SW).

These data show clearly that in the DFS of the cell-wall material a significant change of the ionic relations, as compared with those in sea water, took place. They also demonstrate that a strong selective adsorption has occurred, especially of $\mathrm{Ca}^{+}{ }^{+}$and - to a lesser extent $-\mathrm{Mg}^{++}$, but also of the monovalent ion $\mathrm{K}^{+}$, which is the main intracellular ion of most plant cells. Of special interest is, however, that the relative concentration of sodium, the most important cation of sea water which is commonly present in relatively small amounts in the cell sap of most plants, is significantly reduced in the DFS of the cell-wall material of Valonia.

This may be seen even more clearly from the ratios of $\mathrm{K}^{+}, \mathrm{Ca}^{++}$and $\mathrm{Mg}^{++}$to the $\mathrm{Na}^{+}$content of sea water (I : Na SW) and of the cell-wall extracts (I : Na DFS) listed in Table 2 . The relative accurnulation of these cations becomes even more evident by the ratio I : Na DFS/I : Na SW.

Table 1. Valonia utricularis. Cation concentrations and relations in sea water of $40 \% \mathrm{~S}$ and in the Donnan free space (DFS) of cell-wall preparations. I = concentration of the respective ion in sea water (SW) and in DFS; $\Sigma$ I . . = total concentration of the listed ions in sea water or DFS (for further explanation see text)

\begin{tabular}{|lcccccc|}
\hline Cations & $\begin{array}{c}\text { I SW 40\%o } \\
\left(\mu \mathrm{Val} \mathrm{cm} \mathrm{cm}^{-3}\right)\end{array}$ & $\begin{array}{c}\text { I DFS } \\
\left(\mu \mathrm{Val} \mathrm{cm} \mathrm{cm}^{-3}\right)\end{array}$ & $\frac{\text { I SW }}{\Sigma \text { I SW }}$ & & $\frac{\text { I DFS }}{\Sigma \text { I DFS }}$ & $\frac{\text { I DFS }: \Sigma \text { I DFS }}{\text { I SW }: \Sigma \text { ISW }}$ \\
\hline $\mathrm{Na}^{+}$ & 547 & $651 \pm 19$ & 0.773 & 0.390 & 0.505 \\
$\mathrm{~K}^{+}$ & 12 & $105 \pm 2$ & 0.017 & 0.063 & 3.705 \\
$\mathrm{Mg}^{++}$ & 125 & $582 \pm 35$ & 0.177 & 0.350 & 1.975 \\
$\mathrm{Ca}^{++}$ & 24 & $324 \pm 29$ & 0.034 & 0.195 & 5.375 \\
\hline
\end{tabular}

Table 2. Valonia utricularis. Relations and relative accumulations of the main cations of sea water and of the Donnan free space (DFS) as compared with sodium. I = concentration of the respective ion in sea water (SW) and in DFS; $\Sigma$ I . . = total concentration of the listed ions in sea water or DFS (for further explanation see text)

\begin{tabular}{|cccc|}
\hline Cations & $\mathrm{I}: \mathrm{Na}^{+}(\mathrm{SW})$ & $\mathrm{I}: \mathrm{Na}^{+}(\mathrm{DFS})$ & $\frac{\mathrm{I}: \mathrm{Na}^{+}(\mathrm{DFS})}{\mathrm{I}: \mathrm{Na}^{+}(\mathrm{SW})}$ \\
\hline $\mathrm{K}^{+}$ & 0.022 & 0.161 & 7.32 \\
$\mathrm{Mg}^{++}$ & 0.228 & 0.894 & 3.92 \\
$\mathrm{Ca}^{++}$ & 0.044 & 0.498 & 11.32 \\
\hline
\end{tabular}




\section{DISCUSSION}

The results compiled in Tables 1 and 2 show clearly that especially the divalent ions $\mathrm{Ca}^{++}$and $\mathrm{Mg}^{++}$are selectively adsorbed in the cell-wall material of Valonia utricularis. Eppley \& Blinks (1957) reported similar findings. In killed tissue of the red alga Porphyra perforata they found a $\mathrm{Ca}^{++}$content of 8-10 millimoles or 16-20 mVal per $\mathrm{kg}$ fresh weight. The sucrose free space was determined to $43.6 \%$ of the living tissue. Since uncharged nonelectrolyte molecules are neither attracted nor repelled by the charges of the DFS, the nonelectrolyte FS should also comprise the DFS. In Porphyra perforata the latter can be attributed to the porphyran content of the wall material which according to Cronshaw et al. (1958) amounts to about $50 \%$ and contains large amounts of sulphated polysaccharides $\left(\mathrm{O}^{\prime} \mathrm{Colla}_{i}\right.$ 1962; Mackie \& Preston, 1974) carrying negative charges at the $\mathrm{pH}$ of sea water. Relating the $\mathrm{Ca}^{++}$value to the porphyran content of the wall material which will correspond roughly to a DFS value of $20 \%$ fresh weight, an actual concentration of about 80 to $100 \mu \mathrm{Val} \mathrm{cm} \mathrm{cm}^{-3} \mathrm{DFS}$ is obtained. Sodium, on the other hand, was present only in a concentration of about $200 \mu \mathrm{Val} \mathrm{cm} \mathrm{cm}^{-3} \mathrm{DFS}$. Calculating the ratio of $\mathrm{Ca}^{++}: \mathrm{Na}^{+}$in the DFS of Porphyra a value of $100: 200=0.5$ is obtained which corresponds rather exactly to that calculated for Valonia to 0.498 . Compared with the ratio of $\mathrm{Ca}^{++}: \mathrm{Na}^{+}$in sea water $(=0.043)$ a more than tenfold relative accumulation has obviously occurred in both marine algae.

For the cell wall of Chara australis Dainty et al. (1959) mention a $\mathrm{Ca}^{++}$value of $0.4 \mu \mathrm{Val} \mathrm{cm} \mathrm{cm}^{-2}$ at a wall thickness of $10 \mu \mathrm{m}$, corresponding to $400 \mu \mathrm{Val} \mathrm{cm}{ }^{-3}$ wall material. These authors also found a strong increase of the ratio $\mathrm{Ca}^{++}: \mathrm{Na}^{+}$in the cell walls when the medium concentration of sodium was only slightly reduced in favour of $\mathrm{Ca}^{++}$. This increase of the ratio $\mathrm{Ca}^{++}: \mathrm{Na}^{+}$observed in slices of Porphyra perforata tissue as well as in cell-wall material of Chara australis, and confirmed by our results on cell-wall preparations of Valonia utricularis is, however, hardly surprising. According to the physico-chemical laws governing the Donnan distribution of ions, an exchange between mono- and divalent ions can only take place if two monovalent ions $\left(\mathrm{I}_{\mathrm{i}}^{+}\right)$from one compartment (e.g. DFS) and one divalent ion $\left(\mathrm{I}_{\mathrm{o}}^{++}\right)$of the neighbouring compartment (e. g. WFS) cross the bordering area or potential barrier in opposite directions simultaneously.

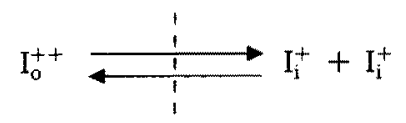

The probability of such an exchange is obviously directly related to the activity products of the ions engaged. Hence equilibrium will be reached if the activity products of the exchanging ions from both compartments are equal, i.e. if

$$
\left(\mathrm{I}_{\mathrm{o}}^{+}\right) \cdot\left(\mathrm{I}_{\mathrm{o}}^{+}\right) \cdot\left(\mathrm{I}_{\mathrm{i}}^{++}\right)=\left(\mathrm{I}_{\mathrm{i}}^{+}\right) \cdot\left(\mathrm{I}_{\mathrm{i}}^{+}\right) \cdot\left(\mathrm{I}_{\mathrm{o}}^{++}\right)
$$

The corresponding relations are then

$$
\frac{\left(I_{i}^{++}\right)}{\left(I_{0}^{++}\right)}=\frac{\left(I_{i}^{+}\right)^{2}}{\left(I_{o}^{+}\right)^{2}}
$$

In other words, in a Donnan system containing mono- and divalent cations as counterions to the fixed anions the accumulation rate of the divalent cations by ion exchange is equal to the second power of the accumulation rate of the monovalent ones. 
This theoretical concept, however, takes only the valency of the ions engaged into account. It is of poor practical value for the estimation of the real distribution of different kinds of ions of the same charge, as present in sea water. Because of different states of hydration and/or polarisation of ions and binding sites compounds may be formed which are only partly dissociated, as is the case with Ca-alginate in brown algae (Kreger, 1962).

Such chemical interrelationships also seem to govern the distribution of the monovalent ions $\mathrm{Na}^{+}$and $\mathrm{K}^{+}$in the cell-wall material of Valonia which is not in accordance with a simple Donnan model, discriminating only between cations of different charge. The actual relations, therefore, of the cations adsorbed in the cell walls of algae can be estimated only by direct chemical determination. The real distribution of the cations revealed thereby may be important for the further steps of mineral metabolism.

Thus the preferential metabolic a c c u m lation of potassium by the cells of most marine and especially freshwater algae may be enhanced by the preferential nonmetabolic adsorption of this ion by the cell walls. By exchange with hydrogen ions, liberated during the metabolism of the cells, the uptake of potassium into the cytoplasm may be facilitated by flattening the steep concentration gradient between the cell sap and the surrounding medium. This may reduce the expenditure of energy which is needed for osmotic work, especially in the case of ion accumulation from diluted media such as pond water; the number of the binding sites available for the adsorption of ions seems to be independent of the outer mineral concentration and only related to the $\mathrm{pH}$ of the environment responsible for the degree of dissociation of the acidic groups of the wall material. This, however, would mean that even under such conditions the amount of ions adsorbed by the binding sites would likewise depend on the relation of the different ions in the surrounding medium and not on their absolute concentration.

This view is supported by a result of Diamond \& Solomon (1959) on Nitella axillaris. In the cell-wall material of this alga exposed to artificial pond water containing only $10^{-4} \mathrm{n} \mathrm{K}^{+}$, they found a concentration even of the monovalent potassium ion of 7200 picomoles per square centimetre cell wall. Since the wall thickness was $210^{-4} \mathrm{~cm}$, the concentration of the adsorbed $\mathrm{K}^{+}$was $3.610^{-2} \mathrm{n} \mathrm{K}^{+}$, corresponding to an adsorptive accumulation from the environment of 360 times! It seems reasonable to suppose that such strong nonmetabolic preaccumulation of a metabolically important ion must also affect the process of its metabolic uptake into the cytoplasm. Further investigations will prove whether this concept is valid.

Acknowledgement. I am indebted to Miss E. Herre for technical assistance and careful performance of the chemical analyses.

\section{LITERATURE CITED}

Briggs, G. E., Hope, A. B. \& Robertson, R. N., 1961. Electrolytes and plant cells. Davis, Philadelphia, $217 \mathrm{pp}$.

Briggs, G. E. \& Robertson, R. N., 1957. Apparent free space. - A. Rev. Pl. Physiol. 8, 11-30.

Burström, H., 1951. The mechanism of ion absorption. In: Mineral nutrition of plants. Ed. by $\mathrm{E}$. Truog. Univ. Wisconsin Press, Madison, 251-260.

Cronshaw, J., Myers, A. \& Preston, R. D., 1958. A chemical and physical investigation of the cell walls of some marine algae. - Biochim.biophys. Acta 27, 89-103. 
Dainty, J. \& Hope, A. B., 1959, Ionic relations of cells of Chara australis. I. Ion exchange in the cell wall. - Aust. J. biol. Sci. 12, 395-411.

Dainty, J., Hope, A. B. \& Denby, C., 1960. Ionic relations of cells of Chara australis. II. The indiffusible anions of the cell wall. - Aust. J. biol. Sci. 13, 267-276.

Diamond, J. M. \& Solomon, A. K., 1959. Intracellular potassium compartments in Nitella axillaris. J. gen. Physiol. 42, 1105-1121.

Diamond, J. M. \& Wright, E. M., 1969. Biological membranes: The physical basis of ion and nonelectrolyte selectivity. - A. Rev. Physiol. 31, 581-646.

Dietrich, G., Kalle, K., KrauB, W. \& Siedler, G., 1975. Allgemeine Meereskunde. Borntraeger, Berlin, $593 \mathrm{pp}$.

Eppley, R. W., 1957. Cation binding and exchąnge in killed red algal tissues. - Exp. Cell Res. 13, 173-174.

Eppley, R. W. \& Blinks, L. R., 1957. Cell space and apparent free space in the red alga, Porphyra perforata. - Pl. Physiol. 32, 63-64.

Epstein, E., 1955. Passive permeation and active transport of ions in plant roots. - Pl. Physiol. 30, 529-535.

Hope, A. B. \& Robertson, R. N., 1956. Initial absorption of ions by plant tissue. - Nature, Lond. 177, $43-44$.

Hope, A. B. \& Walker, N. A., 1975. The physiology of giant algal cells. Cambridge Univ. Press. London, $201 \mathrm{pp}$.

Jacobsen, L., Hannapel, R. J. \& Moore, D. P., 1958. Non-metabolic uptake of ions by barley roots. Pl. Physiol. 33, 278-282.

Kornmann, P., 1934. Osmometer aus lebenden Valoniazellen und ihre Verwendbarkeit zu Permeabilitätsbestimmungen. - Protoplasma 21,340-350.

Kramer, P. J., 1956. The uptake of salts by plant cells. In: Handbuch der Pflanzenphysiol. Ed. by W. Ruhland. Springer, Berlin 2, 290-315.

Kramer, P. J, 1957. Outer space in plants. Some possible implications of the concept. - Science, N. Y. $125,633-635$.

Kreger, D. R., 1962. Cell walls. In: Physiology and biochemistry of algae. Ed. by R. A. Lewin. Acad. Press, New York, 315-335.

Levitt, J., 1957. The significance of "Apparent Free Space" (A.F.S.) in ion absorption. - Physiologia, Pl. 10, 882-888.

Lundegardh, H., 1958. Investigations on the mechanism of absorption and accumulation of salts. I. Initial absorption and continued accumulation of potassium chloride by wheat roots. - Physiologia Pl. 11, 332-346.

Mackie, W. \& Preston, R. D., 1974. Cell wall and polysaccharides. In: Algal physiology and biochemistry. Ed. by W. D. P. Stewart. Blackwell, London, 40-85.

O'Colla, P. S., 1962. Mucilages. In: Physiology and biochemistry of algae, Ed. by R. A. Lewin. Acad. Press, New York, 337-356.

Preston, R. D., 1974. Physical biology of plant cell walls. Chapman \& Hall, London, 300 pp.

Williams, D. E. \& Coleman, N. T., 1950. Cation exchange properties of plant root surfaces. - PI. Soil $2,243-256$. 